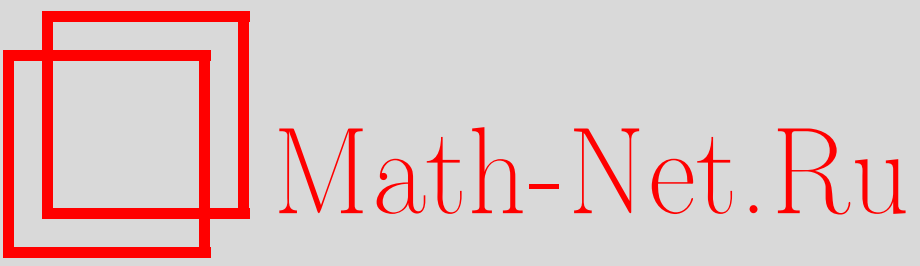

А. Г. Витушкин, В. С. Владимиров, А. А. Гончар, В. В. Напалков, С. М. Никольский, А. М. Седлецкий, П. Л. Ульянов, Ю. Н. Фролов, К восьмидесятилетию Алексея Федоровича Леонтьева (1917-1987), УМН, 1997, том 52, выпуск 3, 189190

DOI: https://doi.org/10.4213/rm1592

Использование Общероссийского математического портала Math-Net.Ru подразумевает, что вы прочитали и согласны с пользовательским соглашением

http://www.mathnet.ru/rus/agreement

Параметры загрузки:

IP : 54.92 .164 .108

26 апреля 2023 г., 14:23:14 


\section{К ВОСЬМИДЕСЯТИЛЕТИЮ \\ АЛЕКСЕЯ ФЕДОРОВИЧА ЛЕОНТЬЕВА (1917 - 1987)}

В 1997 году исполнилось 80 лет со дня рождения выдающегося русского математика, крупнейшего специалиста в области комплексного анализа, лауреата Государственной премии СССР, члена-корреспондента Академии наук СССР Алексея Федоровича Леонтьева.

А. $\Phi$. Леонтьев родился 27 (14) марта 1917 года в селе Яковцево Нижегородской губернии. Он был последним, тринадщатым, ребенком в большой крестьянской семье. В 1927 г. умирает его отец, Федор Харитонович, а вскоре - и мать, Надежда Ивановна, и воспитание младших детей ложится на плечи старших братьев и сестер. После окончания в 1929 г. сельской школы первой ступени Алексей Федорович продолжает учебу в Дзержинске, а затем в Горьком.

После окончания 9 классов в 1934 г. он поступает на физико-математический факультет Горьковского университета и, закончив в 1939 г. университет с отличием, поступает в аспирантуру к профессору И.Р. Брайцеву.

Осенью 1941 г. Алексей Федорович вступает в народное ополчение и до марта 1942 г. участвует в строительстве оборонительных сооружений вокруг Горького. В 1942 г. А.Ф. Леонтьев защищает кандидатскую диссертацию "Дифференциально-разностные уравне-

ния". Он направляется на работу в Марийский педагогический институт в городе Козьмодемьянске, где читает лекции по многим математическим дисциплинам. Бытовые условия были тяжелые, зачастую не было света, керосина, выручала удивительная способность Алексея Федоровича проводить сложные вькладки в уме.

В 1945 г. А. Ф. Леонтьев поступает в докторантуру Математического института им. В. А. Стеклова АН СССР (научный консультант - член-корреспондент АН СССР А. О. Гельфонд). В 1948 г. Алексей Федорович защищает докторскую диссертацию "О классе функций, определенных рядами полиномов Дирихле". Официальные оппоненты академики М. В. Келдыш и М. А. Лаврентьев признали диссертацию выдающейся. Значительно расширенный вариант диссертации составил первую его монограффию "Ряды полиномов Дирихле и их обобщения", вышедшую в 1951 г. в виде 39 тома Трудов МИАН. После защиты он возвращается в Горьковский университет, где заведует кафедрой теории функций.

В 1954 г. А. Ф. Леонтьев переезжает в Москву, здесь он заведует кафееррой высшей математики, а затем кафедрой спецкурсов высшей математики Московского энергетического института, работая по совместительству старшим научным сотрудником Математического института им. В.А. Стеклова. С 1962 г. Алексей Федорович переходит на основную работу в Математический институт, продолжая педагогическую деятельность в МЭИ.

В 1970 г. А. Ф. Леонтьев был избран членом-корреспондентом Академии наук СССР. Начиная с 1971 г. и до конца жизни он работает в Уфе заведующим сектором теории функций Башкирского филиала АН СССР и одновременно заведует кафедрой теории функций и функционального анализа Башкирского университета. Исключительно плодотворными стали для него эти годы в Уфе. Главными трудами жизни А. Ф. Леонтьева являются, без сомнения, три монографии: "Ряды экспонент" (1976), "Последовательности полиномов из экспонент" (1980) и "Обобщения 
рядов экспонент" (1981). Его перу принадлежит также книга "Целые функции. Ряды экспонент" (1983). Эта небольшая по объему мастерски написанная книга содержит материал двух спецкурсов, читавшихся Алексеем Федоровичем в Башкирском университете, и знакомит читателя с современньм состоянием важных разделов комплексного анализа.

За 16 лет, проведенных в Уфе, А. Ф. Леонтьевым проделана поразительная по своим масштабам работа. Отдел физики и математики Башкирского филиала Академии укрепился за счет приезда ряда известных математиков, в том числе и учеников Алексея Федоровича, а также роста местных кадров. Был значительно поднят уровень преподавания математики в БГУ, организованы аспирантура и городской научный семинар. В Уфе неоднократно проводились крупные конференции и симпозиумы по комплексному анализу и смежным вопросам. Не будет преувеличением сказать, что именно благодаря энергии и авторитету А. Ф. Леонтьева Уфа стала крупным математическим центром. Сейчас здесь успешно работает Математический институт, инициатором создания которого был Алексей Федорович. Лучшие из студентов математического факультета БГУ получают стипендию имени А. $\Phi$. Леонтьева.

Алексей Федорович был прекрасным педагогом. На лекциях и в докладах даже трудный материал он умел изложить коротко, ясно и доходчиво. И в Горьком, и в Москве, и в Уфе у него было много учеников. Тридцать пять из них стали кандидатами и восемь - докторами наук.

Научные интересы А. Ф. Леонтьева относятся в основном к теории функций комплексного переменного. А. $\Phi$. Леонтьевым исследовались последовательности полиномов из экспонент и их обобщений и свойства функций, предельных для такого рода последовательностей. Много тонких теорем установлено им в связи с проблемами полноты систем функций, интерполирования и единственности. Изучены вопросы аппроксимации решений уравнений свертки на оси и в комплексной области посредством элементарных решений. Далеко продвинута теория уравнений бесконечного порядка. Доказаны редкие по красоте и изяществу теоремы о квазианалитическом продолжении. Подробно исследованы задачи спектрального синтеза подпространств, инвариантных относительно дифференцирования. Самым важным достижением Алексея Федоровича несомненно следует считать созданную им теорию представления аналитических функций рядами экспонент. Здесь он добился результатов выдающегося значения, превратив ряды экспонент в исключительно эффективньй аппарат аппроксимации функций.

Алексей Федорович вел большую общественную работу. Многие годы он работал в экспертной комиссии по математике ВАК'а, был активным членом редколлегий журнала "Математические заметки" и советско-венгерского журнала "Analysis Mathematica".

А. Ф. Леонтьев был награжден орденами Октябрьской Революции и Трудового Красного Знамени. В 1989 г. ему была присуждена Государственная премия СССР (посмертно).

Стало уже традицией регулярно проводить конференции, посвященные памяти Алексея Федоровича Леонтьева. Вот и сейчас в связи с 80 -летием Алексея Федоровича на его родине, в Нижнем Новгороде проведена конференция по комплексному анализу.

Можно смело говорить о школе Леонтьева - целом отряде математиков, продолжающих и развивающих традиции, заложенные Алексеем Федоровичем. А. Г. Витушкин, В. С. Владимиров, А.А. Гончар, В. В. Напалков,
С. М. Никольский, А. М. Седлечкий, П. Л. Ульянов, Ю. Н. Фролов

\section{СПИСОК ТРУДОВ А. Ф. ЛЕОНТЬЕВА}

[124] О квазианалитической непродолжаемости функции, представленной рядом экспонент // Матем. заметки. 1987. Т. 41. С. 185-193

[125] Ряды и последовательности полиномов из экспонент // Труды МИАН. 1987. Т. 176. C. $308-325$

[126] О системе, биортогональной системе обобщенных экспонент // Актуальные вопросы теории функций. Ростовский ун-т, 1987. С. 11-18

[127] Представление функций рядами обобщенных экспонент // Матем. сб. 1987. Т. 134 (176). C. $496-510$

Начало списка помещено в УМН, 1977, т. 32, вып. 3, с. 191-195 и 1987, т. 42, вып. 5, с. 182. 